ISSN No. 0974-035X

An indexed refereed \& peer-reviewed journal of higher education

\title{
Towards Excellence
}

UGC-HUMAN RESOURCE DEVELOPMENT CENTRE

Gujarat University, Ahmedabad-380009, Gujarat, India

\section{NATIONALISM IN $21^{\text {ST }}$ CENTURY BOLLYWOOD}

\author{
Mr. Jaydeep Padhiyar \\ Mr. Milind K. Solanki
}

\begin{abstract}
Nationalism is as an ideology dealing with the idea of the nation as an ultimate pride for its subjects. In-country like India, everything is plural and diverse nature, region, religion, culture, language etc. And so its nationalism has many shades. Bollywood is the world's largest film industry producing the highest number of movies a year comparing any film industry in the globe. This paper aims to focus on how nationalism gets duplicated by filmmakers in their films. Since Bollywood has a history over more than a century, I have chosen selected films of the 21 st century only.
\end{abstract}

Keywords: Nationalism, Bollywood, History, India

\section{Introduction: Nationalism and India}

Nationalism is a concept dealing with the nation's sovereignty and pride within the territorial boundaries. It is an ideology which deals with people of shared national identity and characteristics. In general, nationalism is as an idea to promote the nation's self-determination. It emerged in Europe in the seventeenth century. When capitalism was raising, and bourgeois was trying to participate in government through democratic representative systems. Nationalism in India developed as a reaction to colonial power who were ruling India before 1947. The flowers of nationalism were blossomed by Great revolt of 1857. For the first time in history, different rulers of India came together and fought against the outsiders. As they all shared common identity and culture, they reacted in a nationalist way. After that Indian National Congress gave air to nationalism in India and especially after Swadeshi Movement lead by Mahatma Gandhi Indian nationalism got a face, a leader to follow, a man who became a great national hero of Indian independence. 
Towards Excellence: An Indexed, Refereed \& Peer Reviewed Journal of Higher Education / Mr. Jaydeep Padhiyar \& Mr. Milind Solanki/ Page 41-50

Apart from Mahatma Gandhi twentieth century has given us many nationalists like $\operatorname{Dr}$ B.R. Ambedkar, SardarVallabhbhai Patel, Jawaharlal Nehru Rabindranath Tagore etc. All travelled globally and well educated. And so we can see their views are quite different than the interpretations of nationalism in the present, especially in popular culture like cinema. History of Indian nationalism is quite jumbling subject where we have the Muslim League and their extremist Muslim religious ideology which resulted ultimately as the Partition of India as well as we have Rastriya Swayam Sevak Sangh with Hindu ideology. In contemporary times nationalism is something soft in some sects of society, it is extreme in some, and somewhere it is merged with patriotism, in some points, it mingled with religious identities and so on. It is full of complexities, and a different opinion for India is a country full of linguistic diversities. The well-established theories of western thinkers possibly can't be adopted in the Indian context. For instant Ernest Gellner's one nation one language theory cannot be appropriate for India, as it has linguistic diversity. A considerable number of dialects prevail in Indian subcontinent.

\section{Nationalism and Bollywood}

After the independence of India Hindi Film Industry popularly known as Bollywood get started evolving widely. The spirit of nationalism was pre-dominant in the pre-independent era for first Bollywood film came in the year of 1913 called 'Raja Harishchandra' by Dada SahebFalke. But people get more into movies in the first phase after independence. The filmmakers like Gurudutt and Bimal Roy gave it a recognizable height in world cinema. Method acting was to introduced in 1951 Hollywood movie 'A Streetcar Named Desire' by Marlon Brando, but it is arguable because Dilip Kumar had done that years before Brando in late 1940s. But the thing was India didn't get that recognition before Gurudutt, Bimal Roy and Satyajit Ray came into the scene.

Bollywood always mingled patriotism and nationalism in movies. And in the early phase of it, 'Mother India' which recognized globally and get nominated in academy awards opened the gate for such type of films. Following this Manoj Kumar came on the stage. He with such iconic movies like 'PurabaurPashchim', 'Shaheed' and 'Upkar' gave 
Towards Excellence: An Indexed, Refereed \& Peer Reviewed Journal of Higher Education / Mr. Jaydeep Padhiyar \& Mr. Milind Solanki/ Page 41-50

Bollywood some finest movies of a kind. And the show gets gone and gone from Manoj Kumar then to Akshay Kumar now.

\section{Nationalism in 21st Century Bollywood}

At the beginning of the new century, Indian cinema also gets a unique style, a new way of expression, new stars and contemporary music. Nationalism which was subject of serious patriotic treatments now shifted on sports. Cricket being the most played game in India, become a medium to express nationalism and patriotism. The Indian cricket team was doing well, and the new generation becomes crazy about it. Sachin Tendulkar was by then already established as one of the finest players of the game. Indian fans believe cricket as religion and Sachin as God. In 2001 director AshutoshGovarikar came up with the movie 'Lagaan: Once Upon a Time in India', a film dealing with nationalism through the game of cricket as history is an inevitable factor in nationalism like a poppy to an opium addict. Govarikar also gave his movie a historical treatment by setting it in pre-independent India.

Britishers were imposing a hefty tax on villagers and a young man challenging Britishers in the game of cricket. Ultimately villagers win the game by beating colonizers in their own national game which the villagers even don't know to play initially. And as a winner, they get a deal of three years tax-free. This historical fiction made a massive impact on the audience that it gained national awards and earned the nomination to the Oscar. Script wise the movie goes around the subject of nationalism, and its music takes it even closer and closer. A.R. Rahman's composition and Javed Akhtar's lyrics makes Lagaan a full-on movie of nationalism and patriotism. 'ChaleChalo' and 'O Mitwa' are the songs which fill a new strength to the colonized villagers. Where 'O Mitva' appeals listeners not to be afraid of any tyrannies, for the earth and sky belong to the native people. And 'ChaleChalo' gives the message to be united and walk along with all the confidence and strength.

No matter how thick the shoe sole is, it wears out. (Lagaan) 
Towards Excellence: An Indexed, Refereed \& Peer Reviewed Journal of Higher Education / Mr. Jaydeep Padhiyar \& Mr. Milind Solanki/ Page 41-50

This dialogue shows villagers the hope that colonial time will vanish one day and brings the feeling of nationalism in them. And while watching the movie, Indian subjects would relate themselves with that dialogue for they knew the "the shoe sole has worn out."

The same director came up with 'Swades' in 2004. Again a very nation oriented movie, but this time he shifted from cricket to science. India at the time was enjoying remarkable recognition in the field of science and technology under the leadership of President Dr A.PJ. Abdul Kalam. Indian Space Research Organization (ISRO) developed as one of the groundbreaking space research organizations of the world. The movie 'Swades' shows the scientific advancement of an Indian scientist who after being trained in NASA returns to his motherland and works for the improvement of rural India. The movie is undoubtedly a practical and reasonable effort to lit the candle of nationalism into all Indians, especially the intellectuals and educated people who leave the country and gives their services to foreign countries. At the same time, their nation needs them for its sovereignty and development.

I don't believe our country is the best in the world, but I do think

that we have the potential and strength to make our country the best. (Swades)

This dialogue by the main character played by Shah Rukh Khan makes it clear that the movie is not prioritizing the blind nationalism. Still, it instead accepts that there are countries who are better than us, but we Indians also have the courage and strength to make our country best. And this ideology, this thinking is I think the best example of nationalism.

In the same year, 2004 director Farhan Akhtar came up with the movie 'Lakshaya' this movie was a tribute to Indian soldiers who fought in 1999 Kargil War, said the writer and lyricist of the film Javed Akhtar in an interview. He visited Kargil so he can write the script. As come critics say, an attempt of Javed Akhtar to express his feeling of nationalism. The movie deals with the topic of a privileged, rich, aimless young man who in circumstances of his uncleared aim ends up joining the Indian Army, where he becomes a changed man. A man with a goal, a mature human being and a 
Towards Excellence: An Indexed, Refereed \& Peer Reviewed Journal of Higher Education / Mr. Jaydeep Padhiyar \& Mr. Milind Solanki/ Page 41-50

stable and inspiring youth. One can call it a coming of age story, but the movie has much more to convey. It is one of the most satisfactory attempt to describe the feeling of nationalism without being extremist or highly historical. The film played a vital role in aimlessly roaming youth to change their direction. Many army officers today openly claims that they've joined the Indian Army after watching 'Lakshya.'

There is a difference between them and us, and it should stay that way. It is the Indian Army. We maintain decency even in our enmity. (Lakshya)

This dialogue delivered by Amitabh Bachchan gives goosebumps of nationalism to the audience. India's pride and power both get justified by just one conversation. The movie fills up the feeling of patriotism and nationalism by such dialogues.

A billion people who trust us to stay awake so they may sleep. This trust is a great honour and a great responsibility. (Lakshya)

This dialogue delivered by Amitabh Bachchan gives goosebumps of nationalism to the audience. India's pride and power both get justified by just one conversation. The movie fills up the feeling of patriotism and nationalism by such dialogues.

Next in this paper is RakeyshOmprakashMehra directed 2006 film 'Rang De Basanti'. This movie deals with the principles of Indian communist freedom fighters Chandrasekhar Aazad and Bhagat Singh. Bhagat Singh enjoys the highest respect from the 21st-century youth among all freedom fighters maybe because he is a youth icon. In the movie, a British film studies student arrives India to shoot a short film on five Indian freedom fighters of Indian Revolutionary Movement, which are ChandrashekharAazad, Bhagat Singh, RamprasadBismil, ShivramRajguru and Ashfaqullah Khan. She casts five young men for these roles. And these five men gradually inherits the principles of those five freedom fighters whose role they are playing. Finally, just as those freedom fighters fought against the tyrant rule of colonial powers. These five young men fight the corruption and injustice of the government. The film enlightens the audience with those freedom fighters and gives motivational to citizens to fight corruption and injustice.

To live life, there are only two ways 
one whatever is happening let it happen, keep tolerating it or else take the responsibility to change it. (Rang De Basanti)

Even now whose blood doesn't boil, then that blood is water, the youth who doesn't serve the country is a waste. (Rang De Basanti)

No country is perfect ... one has to make it better. (Rang De Basanti)

These dialogues convey the primary function of the film, which is, of course, nationalism. Now, this nationalism is quite different from 'Swades' or 'Lakshya'. This nationalism is quite radical in tone, but at the critical situation, it has in action. For in this movie, they fight against the government itself because for the sake of the nation itself. The film is among the forerunner in charts among youth; activism started on the internet, people started raising voice against corruption in the bureaucracy. In the year, 1999, the impact was observed Jessica Lall Murder Case protests started taking place for justice.

Chak De! India came in 2007. Director Shimit Amin with a power pack script by Jaideep Sahni brought a movie on Indian Women's Hockey. The film hit many marks at the same time as women's place in sports, underestimation of their abilities, patriarchal system and so on. But apart from this, the movie stands as a vision of a former Hockey player to win the gold. His dream to make his country win the gold medal and get back his and his nation's pride. And so he becomes the coach of National Women's Hockey Team and trains them ending up by winning gold.

For every country, sports play a vital role for the spectators. For example, an Australian can say that he is from the country who won five cricket world cups. A Spanish can say that he belongs to the country where the F.C. Barcelona football team operates. It is how people relate themselves to sports. Hockey is India's national game. In any country, citizens have respect for their national competition. And so they wish their country to be the champion of that game. This idea is a kind of nationalism which exists in sports. And the movie Chak De! India brings this like anything.

I can't hear nor see the name of the states ... I can only attend one country name I-N-D-I-A. (Chak De! India) 
Towards Excellence: An Indexed, Refereed \& Peer Reviewed Journal of Higher Education / Mr. Jaydeep Padhiyar \& Mr. Milind Solanki/ Page 41-50

This team needs only players who are playing for India first, India ... then for their teammates... and after that, if a little life is left then for self ... not for a state government job or a railway flat. (Chak De! India)

As these two dialogues suggest that the movie, through its character coach Kabir Khan player by Shah Rukh Khan, presents a man who wants every player to be Indian first. And then of her state. The nation should come first according to him. Because on an international level everybody knows them as Indians. These two dialogues can travel successfully in any situation where the encouragement of nationalism is needed.

Apart from the five milestones movies, there are movies like 'Airlift', URI-The Surgical Strike' and 'Raazi' which has based on real incidents and their treatment as cinemas is appreciable. As nationalism stands for nation's pride and sovereignty these movies deals with some serious issues like 'Airlift' with 1990 airlift of Indians from Kuwait, 'URI' with the surgical strike operation of Indian Army in Pakistan, and 'Raazi' with a spy operation during Indo-Pak War 1971. When a movie is an adaptation of actual events, it gets more attractive because everyone wants to visualize the things that happened in the past. And when such a movie arrives onshore, lots of people go on and on to see the ship. That happened with these movies, and ultimately they produced the feeling of nationalism and patriotism among Indian subjects.

We are something if we are together ... or else we are nothing. (Airlift)

This particular dialogue shows the main aim of nationalism where unity is the core concept among the people of same identity and nationality. The movie deals this with Indian expatriates in Kuwait who are in trouble because Saddam Hussain attacked Kuwait.

'Raazi' is the movie which gave Indians a perfect patriotic song "Ae Watan" composed by Shankar-Ehsaan-Loy and penned by Gulzar. The song in itself is not some hardhitting extreme advocate of the Indian nation, but rather it deals with the idea of India's pride and sovereignty in a very light mood. Film Companion's Sankhayan Ghosh of the briefs, 

Jaydeep Padhiyar \& Mr. Milind Solanki/ Page 41-50

the lyrics "stands out for its simplicity, and context. Ae Watan appeals to the hardened cynics from both sides of the ideological centre; it reminds us that patriotism isn't necessarily a bad thing, all the while showing the price we pay for it". (Film Companion)

\section{Conclusion}

History is something that gives the nation its identity. Historical changes are the reason aback the emergence of nationalism. In these movies, society changes by when it require nationalism occurs. It brings positive outcomes when it's inclusive, just like the nationalism shown in the film 'Swades'. But when it goes exclusive, it can be a disaster like the nationalism in 1930s Nazi Germany. But inclusive nationalism can be helpful in nation-building like in some of the African countries did. That is something the world needs. And that is a kind of nationalism which can help the nation. In a country like India, where there is a vast diversity in religions, sometimes the wrong notion of socalled nationalism takes place. The exclusive one. And that often gets resulted in riots and religious tensions. We need to replace this notion with the inclusive nationalism. And for that, every layer of society has to participate especially Bollywood, which can make a significant impression on the masses. 
Towards Excellence: An Indexed, Refereed \& Peer Reviewed Journal of Higher Education / Mr. Jaydeep Padhiyar \& Mr. Milind Solanki/ Page 41-50

\section{Work Cited}

Hobsbawm, E.J. Nations and Nationalism since 1780. $3^{\text {rd }}$ ed., Cambridge, 1992. Print.

Bose, Mihir. Bollywood: A History. Lotus Collection Roli Books. 2006. Print.

Gowariker, Ashutosh. Director. Lagaan: Once Upon a Time in India. Aamir Khan Productions.2001.

Gowariker, Ashutosh. Director. Swades.Ashutosh Gowariker Productions. 2004.

Akhtar, Farhan. Director. Lakshya. RiteshSidhwani, ExcelEntertainment. 2004.

Mehra, Rakeysh,Omprakash. Director. Rang De Basanti. RakeyshOmprakashMehra Pictures. 2006.

Amin, Shimit. Director. Chak De! India. Yash Raj Films. 2007.

Menon, Raja, Krishna. Director. Airlift. Viacom 18 Motion Pictures. 2016.

Dhar, Aditya. Director. Uri: The Surgical Strike. RSVP Movies. 2018.

Gulzar, Meghna. Director. Raazi. Junglee Pictures, and Dharma Productions. 2018.

Ghosh, Sankhayan. “'Ae Watan' From Raazi Reminds Us That Patriotism Isn't Necessarily A Bad Thing."Film Companion, 12 May 2018.filmcompanion.in/music/raazi-ae-watan-alia-bhatt-patriotism-songreview/amp/. 
Towards Excellence: An Indexed, Refereed \& Peer Reviewed Journal of Higher Education / Mr. Jaydeep Padhiyar \& Mr. Milind Solanki/ Page 41-50

Wikipedia contributors. "1990 airlift of Indians from Kuwait." Wikipedia, The Free Encyclopedia. Wikipedia, The Free Encyclopedia, 24 Feb. 2020.

- - -. "Indian nationalism." Wikipedia, The Free Encyclopedia. Wikipedia, The Free Encyclopedia, 1 Feb 2020.

- - -. "Gellner's theory of nationalism." Wikipedia, The Free

Encyclopedia.Wikipedia, The Free Encyclopedia, 14 Feb. 2020.

Jaydeep Padhiyar
Scholar and Translator,
Bhuj-Kachchh
$\&$
Milind K. Solanki
Assistant Professor, Department of English, KSKV Kachchh
University, Bhuj

